\title{
Trabalho e sofrimento psíquico: histórias que contam essa História
}

\author{
Work and psychological distress: stories that make History
}

Trabajo y sufrimiento psíquico: historias que cuentan esa Historia

TRABALHO E SOFRIMENTO PSÍQUICO: HISTÓRIAS QUE CONTAM ESSA HISTÓRIA. Cappellano T, Carramenha B. São Paulo: Haikai Editora; 2019. 173 p. ISBN 978-6580188-49-9.

doi: 10.1590/0102-311X00046120

O trabalho como instituição social é uma categoria que desperta o interesse de diversas áreas que se ocupam em examiná-lo e entendê-lo como parte fundamental do engendramento das relações político-sociais, como a História, a Sociologia e a Antropologia do Trabalho, até o seu papel na formação humana com as concepções filosóficas, abordagens psicológicas e médicas ou mesmo as investigações psicanalíticas a respeito da relação sujeito-trabalho. Além disso, não deixa de ser um tema central das políticas institucionais e públicas, como também dispositivo que baseia as relações de poder entre os indivíduos.

Neste aspecto, o livro Trabalho e Sofrimento Psíquico: Histórias que Contam essa História, lançado pela Haikai Editora, trata-se de uma pesquisa que passa a fazer parte das controvérsias a respeito do que este significa e sua relação com os sujeitos individual e coletivo, a fim de "compreender o sofrimento psíquico oriundo do trabalho (ou da sua ausência)" (p. 15). O campo de reflexão sobre a relação entre trabalho e subjetividade não é novo, pontuado desde o início do século XX com as demandas do taylorismo, passando pelas contribuições das áreas que alimentaram os estudos da Psicopatologia, sobretudo a psicanálise que, por sinal, influencia uma área mais específica criada na década de 1980, a saber, a Psicodinâmica do Trabalho, com Christophe Dejours - pilar teórico das análises desse estudo.

No entanto, o que faz com que a obra seja de suma importância nesse debate é que ela pode ser lida dialeticamente sob três perspectivas: a primeira, como uma análise sociológica da relação entre o sistema capitalista e sujeitos inseridos nesse modo de produção, mediados pelo trabalho; a segunda, como uma contribuição às ciências psicológicas no que refere ao adoecimento psíquico atual causado não só pelas demandas de trabalho, mas inclusive pela falta dele - essa segunda parte é central dada moral social partilhada em torno do trabalho; e a terceira, em síntese, como uma lente psicossociológica que enxerga o trabalho como um nexo causal posto entre o sistema neoliberal e o adoecimento mental contemporâneo e as estratégias defensivas adotadas pelos sujeitos que procuram se proteger do sofrimento.

O livro inicia-se com o prefácio do sociólogo Ruy Braga que começa suas considerações com uma análise histórica e de conjuntura sobre a falência do sistema neoliberal, sobretudo na América Latina, e mostra como os conflitos entre acumulação do capital e legitimação política, assim como o acúmulo de contradições da última década, seria uma chave de leitura para entender 
a ascensão da extrema direita no Brasil. O sociólogo relaciona essas radicalizações com as transformações nas facetas do trabalho no interior das novas estruturas políticas e introduz a importância da leitura de obras como a pesquisa Trabalho e Sofrimento Psíquico, que desvela uma emergência maior de uma ruptura "a fim de fazer frente à ameaça representada pelo casamento monstruoso do ultraneoliberalismo econômico com o neofascismo político" (p. 33).

A pesquisa se construiu a partir da consonância entre as técnicas qualitativa, quantitativa e entrevistas com pessoas de diferentes camadas sociais (divididas no desenho metodológico em cinco grupos: feridos, sobreviventes, heróis, guerreiros e vencedores), cujos resultados se distribuíram em 5 capítulos: O Trabalho é Sempre Violência; O Mercado Não Sabe o que Quer; O Sofrimento Vem de Cima; Renda Importa, Acesso à Saúde Escraviza e o Ócio Liberta; e $O$ (Não) Futuro do (Não) Trabalho. Dois deles podem ser lidos como uma imagem geral dos demais achados. Em O Trabalho é Sempre Violência, a pesquisa mostra como violações, que vão das pequenas incivilidades à danos físicos e psicológicos, fazem parte do eixo trabalhista como motor de determinadas relações. São peças que fazem parte da história dos sujeitos desde a infância (conflitos basais na família), são as angústias causadas pela pressão de um trabalho constante, a autoviolência como presunção de "sucesso", a degradação de relações afetivas pelo trabalho etc. Poderíamos pontuar que o que se apresenta neste capítulo é a forma como se constitui um amálgama entre a psicopatologia da violência e a psicopatologia da precarização.

Já no capítulo O Sofrimento Vem de Cima enfrenta-se a dúvida sobre quem carrega a culpa dessas desolações. Dois pontos merecem destaque: o primeiro deles é que uma hierarquia existe (e nela se encontra a violência no exercício do poder), assim como "a responsabilização do sistema é um consenso entre todos, independentemente do tipo de relação de trabalho" (p. 99). O “capitalismo aparece como o indutor do modelo de gestão das empresas, cada dia mais desumano devido à competitividade que promove entre quem está dentro e fora do mercado formal" (p. 99), o que não deixa de ser confirmado principalmente pelas mais novas modificações nas estruturas desse sistema e o aumento subsequente da desigualdade, da flexibilização e da precarização ${ }^{1}$. O segundo ponto, que se encontra no eixo de análise desse capítulo ("O gênero e a cor da precarização”), é que a mulher negra é a principal afetada nesse arcabouço, o que corrobora os resultados tanto da coleta quantitativa da própria pesquisa, como as várias outras pesquisas, relatórios e dossiês que constatam a mesma questão 2,3,4.

Os demais achados apresentam as incoerências do mercado no que se refere às altas exigências e a baixa remuneração, falta de oportunidade, fraudes na seleção, desrespeito e preconceito; além disso, discorre-se sobre o acesso a renda como precursor da precariedade do trabalho pelo terror que seria enfrentar o SUS e os desejos despertados pela ideologia do empreendedorismo fadados ao fracasso; e, por fim, apresenta-se como as questões sociais embutidas no trabalho não são pensadas, nem enfrentadas e o seu (não) futuro não faz parte da reflexão da maioria. Portanto, ao interpretarmos a obra como uma lente psicossociológica, podemos ainda acrescentar que ela transcende uma leitura da realidade do sistema neoliberal e sua relação com a psicologia dos sujeitos concretos que afirmaram sofrer pelo trabalho (78\% dos entrevistados, sendo um dado que chega a $85 \%$ no caso das mulheres negras). Ela carrega um teor crítico-social que desvela os impasses contemporâneos do mundo do trabalho e seus desdobramentos, dos direitos básicos, das relações de gênero, raça e classe, do político, da economia e embasa a necessidade de rupturas reais contra um passado, um presente e um horizonte de mais obscuridades e mais violência. Não à toa, os resultados podem ser perfeitamente relacionados à outras pesquisas das ciências que se dedicam às questões ocupacionais que mostram como a precarização social e do trabalho no capitalismo é um novo e um velho fenômeno diretamente relacionado aos adoecimentos psíquicos 5,6.

Por fim, Trabalho e Sofrimento Psíquico carrega - de forma quase poética, inclusive, no subtítulo - a crença de que: as histórias dizem, mesmo sem dizer, algo sobre a nossa História. São as histórias reais, ouvidas e registradas, que de fato revelaram como vivenciamos a nossa Histó- 
ria, que por sua vez é a biografia de milhares de pessoas silenciadas pela violência, marcadas pela exploração, regimes de acumulação, segregação e preconceitos. "Essa História” de contradições e crises é a que faz com que o mesmo significante, a saber, "trabalho", carregue a ambiguidade de afetar à todos, mas com significados e sentidos diferentes a depender se você é uma mulher negra periférica ou ocupa um cargo de alto escalão - mostrando que a realidade da estratificação, inclusive na atividade laboral, é determinante de graus, inclusive, de vidas mais ou menos vivíveis, e que o silenciamento e a negação do sofrimento nas ocupações é, como bem pensou Dejours, a banalização das injustiças sociais.

Emilly Saas Alves 1

1 Universidade Federal do Vale do São Francisco, Petrolina, Brasil.

emilllysaas@hotmail.com

\section{Informação adicional}

ORCID: Emilly Saas Alves (0000-0002-7962-112X).

1. Oliveira ENP, Moita DS, Aquino CAB. O empreendedor na era do trabalho precário: relações entre empreendedorismo e precarização laboral. Rev Psicol Polít 2016; 16:207-26.

2. Silva DL, Silva IT, Fernandes J, Nunes J, Balduino P, Faria S, et al. Festival da mulher afro-latino-americana e caribenha: mulheres negras no mercado de trabalho. Brasília: Instituto de Pesquisa Econômica Aplicada; 2012.

3. Vieira B. Mulheres negras no Brasil: trabalho, família e lugares sociais [Dissertação de Mestrado]. Campinas: Universidade Estadual de Campinas; 2018.

4. Marcondes MM, Pinheiro L, Queiroz C, Querino AC, Valverde D. Dossiê mulheres negras: retrato das condições de vida das mulheres negras no Brasil. Brasília: Instituto de Pesquisa Econômica Aplicada; 2013.

5. Druck G. Trabalho, precarização e resistências: novos e velhos desafios? Caderno CRH 2011; 24:37-57.

6. Franco T, Druck G, Seligmann-Silva E. As novas relações de trabalho, o desgaste mental do trabalhador e os transtornos mentais no trabalho precarizado. Rev Bras Saúde Ocup 2010; 35:229-48. 